\title{
JOINT ATTENTION, UNION WITH GOD, AND THE DARK NIGHT OF THE SOUL
}

\section{DONALD BUNGUM}

\author{
St. Louis University
}

\begin{abstract}
Eleonore Stump has argued that the fulfilment of union between God and human beings requires a mode of relatedness that can be compared to joint attention, a phenomenon studied in contemporary experimental psychology. Stump's account of union, however, is challenged by the fact that Mother Teresa, despite her apparent manifestation of the love of God to others, herself experienced an interior 'dark night of the soul' during which God seemed to be absent and to have rejected her completely. The dark night of the soul poses a problem for Stump's account, since, if anyone had a union of divine love with God, it would seem that Mother Teresa did. Nevertheless, I argue that the isolation and abandonment of Mother Teresa's dark night are contrary to the conditions assumed to be required for joint attention with God. As an alternative to Stump's account, I suggest that the dark night of the soul might be better understood by reference to a combination of joint attention and blindsight, according to which interpersonal closeness might be realized through a consistent pattern of external actions without, however, a direct awareness of one person by the other.
\end{abstract}

\section{INTRODUCTION}

Cognitive scientists, psychologists, and philosophers have recently made great strides in characterizing the phenomenon of joint attention, and although joint attention has proved difficult to define philosophically, it is nevertheless easy to illustrate. For example, joint attention occurs when a father looks intently into the eyes of his baby daughter, and she looks intently into his. Both father and daughter are aware not only of the other person, but also of the other's awareness, and further of the other's 
awareness of their own awareness. ${ }^{1}$ Other examples of joint attention are commonplace in daily life and include pointing, reciprocal smiling, gazefollowing, and so on. ${ }^{2}$ In each case, joint attention is marked by a certain mutuality and 'out-in-the-openness' that solitary attention lacks.

Research into the nature of joint attention has also found fruitful applications in philosophical theology. For example, Eleonore Stump has recently argued for an analysis of the theological virtue of charity (caritas, also sometimes translated as 'divine love' or simply 'love') that includes joint attention as one of its critical components. ${ }^{3}$ On her account, charity involves union with God, and the fulfilment of union with God requires both mutual closeness and mutual personal presence. In Stump's view, mutual personal presence occurs between persons only if they share attention, and the relevant 'sharing' is that of joint attention, which minimally involves 'a shared awareness of the sharing of the focus' with another person. ${ }^{4}$ Stump's account of charity is attractive, since charity is what most closely unites human beings with God, and, between persons who love each other, the closest interactions seem to involve joint attention.

By making joint attention necessary for the fulfilment of interpersonal union, however, Stump's account appears to encounter difficulties when faced with the so-called 'dark night of the soul', an advanced stage of the

${ }^{1}$ John Campbell, 'Joint Attention and Common Knowledge', in Joint Attention: Communication and Other Minds: Issues in Philosophy and Psychology, ed. by Naomi Eilan and others (Oxford: Oxford University Press, 2005), pp. 287-297.

2 Among adults, there are also many manifestations of joint attention, such as mirroring behaviours, although such manifestations between adults are often masked by other complex interpersonal interactions. For joint attention and second-person interaction in adults, see Leonhard Schilbach and others, 'A Second-Person Neuroscience in Interaction', Behavioral and Brain Sciences, 36 (2013), 441-462.

${ }^{3}$ Eleonore Stump, Wandering in Darkness: Narrative and the Problem of Suffering (Oxford; New York: Oxford University Press, 2010), chap. 4-6. Stump offers a series of arguments for the claim that joint attention is possible between God and human beings. I accept these arguments, and, for the purposes of this paper, I will simply assume that joint attention is possible between God and humans. This possibility, of course, presupposes that God exists, that he possesses intellective and volitional states that can be understood by human beings, and that it is possible for him to enter into the sorts of causal relationships required for joint attention to occur.

${ }^{4}$ Stump, Wandering in Darkness, pp. 116-160; R. Peter Hobson, 'What Puts the Jointness into Joint Attention?', in Joint Attention: Communication and Other Minds: Issues in Philosophy and Psychology, ed. by Naomi Eilan and others (Oxford: Oxford University Press, 2005), p. 185. 
spiritual life marked by the subjective sense that God has abandoned and rejected one. ${ }^{5}$ The dark night of the soul has recently attracted some interest, since the private correspondence of Mother Teresa of Calcutta reveal that she spent much of her life in this condition. ${ }^{6}$ Thus Mother Teresa stands as a well-documented case of a human person seeming to possess a profound personal union with God despitelacking joint attention with him. ${ }^{7}$ Together, Mother Teresa's apparent union with God and her crushing experience of his absence seem to present a counterexample to Stump's claim that a human being possesses the fulfilment of personal union with God only if she shares attention with God.

In this paper, I consider the compatibility of interpersonal union and joint attention in Mother Teresa's experience of the dark night of the soul. I argue that, in the face of the theological data, the prospects are not good for the claim that joint attention alone provides an adequate analogical understanding for charity and union with God at this purportedly advanced stage of the spiritual life. I then offer an alternative account of union based on the phenomenon of blindsight, and I show how this account can be defended against the criticisms raised for Stump's view.

\section{JOINT ATTENTION AND 'PRESENCE TO AWARENESS'}

It is helpful to begin by thinking in general about joint attention and what is present to the awareness of a participant in joint attention. If God's absence is part of the problem of Mother Teresa's dark night, as she experienced it, what then is the 'presence' of another person that characteristically belongs to joint attention? Recent scholarship suggests that joint attention makes two things present to its participants: (a) an iterative awareness of the other's awareness, ${ }^{8}$ and (b) an introspective awareness that one and the other are presently sharing attention. ${ }^{9}$

${ }^{5}$ On the dark night, see The Dark Night of the Soul and its introduction in John of the Cross, The Collected Works of St. John of the Cross, ed. by Kieran Kavanaugh and Otilio Rodriguez (Washington, D.C: Institute of Carmelite Studies, 1979). For more recent accounts, see Reginald Garrigou-Lagrange, Christian Perfection and Contemplation, According to St. Thomas Aquinas and St. John of the Cross, ed. by M. Timothea Doyle (St. Louis, MO: B. Herder Book Co., 1937); Antonio Royo Marin and Jordan Aumann, The Theology of Christian Perfection (Dubuque, Iowa: Priory Press, 1962).

${ }^{6}$ Mother Teresa, Mother Teresa: Come Be My Light: The Private Writings of the Saint of Calcutta, ed. by Brian Kolodiejchuk (New York: Image, 2007). (Henceforth, 'Teresa')

${ }^{7}$ See the collection of Mother Teresa's personal reflections contained in Teresa. 
Turning first to the iterative character of joint attention, it will be useful first to examine a case in which joint attention fails to exist between two persons. ${ }^{10}$ Consider two people facing each other, separated by a thick pane of glass. Suppose that each person falsely believes that the glass separating him from the other person is a one-way mirror, one that allows him to see the other person, but that prevents the other person from seeing him. In this case, each person really sees the other person, but falsely believes that the other cannot see him. Clearly, this situation is far from having the full openness of joint attention, and the reason is that, since each person believes that the other person cannot see him, neither is in a position to perceive that the other perceives him, nor that he perceives that the other perceives that he perceives him, nor any other higher-order iteration of ' $y$ perceives that $\mathrm{x}$ perceives that $\mathrm{y}$ perceives x.' While it remains disputed exactly how the iterative openness of joint attention should be characterized, for the purposes of this paper, it is sufficient to note the uncontroversial point that the openness of joint attention serves as an experiential, categorical basis for x's deriving infinitary knowledge of the direction of y's attention. ${ }^{11}$ That is, even if the participants never go on to state explicitly any of the higher order iterations of their mutual awareness in joint attention, nevertheless the experience of joint attention makes knowledge of such states in principle available to sufficiently mature participants capable of analytic reasoning. I will call the availability of such infinitary knowledge to each participant the 'iterative availability' of joint attention.

In addition to iterative availability, however, joint attention also involves a certain 'introspective availability', which is nothing more than

${ }^{8}$ This awareness is iterative in the sense that for two persons $\mathrm{x}$ and $\mathrm{y}$ jointly attending each other, $\mathrm{x}$ is aware of $\mathrm{y}$, and $\mathrm{x}$ is aware that $\mathrm{y}$ is aware of $\mathrm{x}$, and $\mathrm{x}$ is aware that $\mathrm{y}$ is aware that $\mathrm{x}$ is aware of $\mathrm{y}$, and so on. In principle, these nested iterations could be expanded infinitely.

${ }^{9}$ Here I draw on discussions in Campbell, 'Joint Attention and Common Knowledge'; John Campbell, 'An Object-Dependent Perspective on Joint Attention', in Joint Attention: New Developments in Psychology, Philosophy of Mind, and Social Neuroscience, ed. by Axel Seemann (Cambridge, MA: MIT Press, 2011), pp. 415-430; Christopher Peacocke, 'Joint Attention: Its Nature, Reflexivity, and Relation to Common Knowledge', in Joint Attention: Communication and Other Minds: Issues in Philosophy and Psychology, ed. by Naomi Eilan and others (Oxford: Oxford University Press, 2005), pp. 298-324.

${ }^{10}$ Adapted from Peacocke, p. 299.

11 For views regarding the iterative character of joint attention, see Peacocke; Campbell, 'Joint Attention and Common Knowledge'; Michael Wilby, 'The Simplicity of Mutual Knowledge,' Philosophical Explorations, 13 (2010), 83-100. 
each participant's ability to be aware by introspection that he is currently sharing attention with the other. Consider again the two people facing each other. Another way to see that joint attention fails between them is to recognize that neither person is in a position to perceive that the other is jointly attending with him. Since each person falsely believes that the other cannot see him, neither will experience the full openness of shared attention as present between them. On the other hand, suppose that the two people simultaneously realize that the glass before them is not a one-way mirror, say, by an announcement over a loudspeaker that was manifestly audible to both of them. Suddenly, the openness and jointness of their attention would be present to the consciousness of each participant, such that each could be aware that he was now sharing attention with the other simply by introspection.

Joint attention, then, seems to require that two sorts of availability be present to the awareness of each participant. The first, which I have called iterative availability, is the availability to each participant of a certain sort of knowledge about the other participant. This knowledge can be described by an iterative and potentially infinite sequence, since it is gained by deducing from the full openness of joint attention propositions of the form ' ... x perceives that y perceives x'. Even if neither participant carries out any such deductions, joint attention is marked by making this sort of knowledge possible for its participants. ${ }^{12}$ The second sort of availability, which I have called introspective, is the availability of an introspective awareness about the situation in which the participants find themselves. When joint attention occurs between two people, the openness of their shared attention is present to the consciousness of each participant, such that each can know by introspection that he presently shares attention with the other. Such introspective availability can obtain even if neither participant possesses the concepts of 'shared attention' or 'mutually manifest openness', since the phenomenon can be familiar to and recognizable by each participant even while its names or theoretical formulations are not.

12 Campbell $(2005,2011)$ argues that it is only by being the experiential basis for this sort of knowledge that joint attention can help solve the 'Two Generals' problem first elaborated in E. A. Akkoyunlu, K. Ekanadham, and R. V. Huber, 'Some Constraints and Tradeoffs in the Design of Network Communications', in Proceedings of the 5th ACM Symposium on Operating Systems Principles, ed. by James C. Browne and Juan RodriguezRossell (New York: ACM, 1975), pp. 67-74. 


\section{MOTHER TERESA AND SPIRITUAL FACULTIES}

Given these claims concerning joint attention, it will be useful next to turn to the theological data concerning Mother Teresa's dark night of the soul. The aim is to see whether the relevant phenomenological aspects of Mother Teresa's darkness, as recounted to her confessors and spiritual directors between 1947 and 1997, are consistent with the claim that Mother Teresa engaged in joint attention with God during this time, as expected by Stump's analysis of the meaning of charity. In order to do this, I will first rule out the view that Mother Teresa failed to engage in joint attention with God merely because she lacked the spiritual or psychological faculties necessary to do so. On the contrary, Mother Teresa's writings suggest that she possessed powers of spiritual discernment equal to those of great mystics such as St. John of the Cross or St. Teresa of Avila. ${ }^{13}$ After establishing this claim, I move to analyze how the sense of isolation and abandonment is present in Mother Teresa's writings during her dark night. On the basis of this analysis, I will show why it is reasonable to think that no one in such a spiritual state could experience the presence of either the iterative or the introspective availability required for joint attention with God.

Turning to the faculties required for joint attention, we can note that there are many reasons why human beings can fail to share attention

${ }^{13}$ Consider, for example, a typical report from St. Teresa of Avila: 'One day when I was at prayer ... I saw Christ at my side - or, to put it better, I was conscious of Him, for I saw nothing with the eyes of the body or the eyes of the soul [the imagination]. He seemed quite close to me and I saw that it was He. As I thought, He was speaking to me. Being completely ignorant that such visions were possible, I was very much afraid at first, and could do nothing but weep, though as soon as He spoke His first word of assurance to me, I regained my usual calm, and became cheerful and free from fear. All the time Jesus Christ seemed to be at my side, but as this was not an imaginary vision I could not see in what form. But I most clearly felt that He was all the time on my right, and was a witness of everything that I was doing ... if I say that I do not see Him with the eyes of the body or the eyes of the soul, because this is no imaginary vision, how then can I know and affirm that he is beside me with greater certainty than if I saw Him? If one says that one is like a person in the dark who cannot see someone though he is beside him, or that one is like somebody who is blind, it is not right. There is some similarity here, but not much, because a person in the dark can perceive with the other senses, or hear his neighbour speak or move, or can touch him. Here this is not so, nor is there any feeling of darkness. On the contrary, He appears to the soul by a knowledge brighter than the sun. I do not mean that any sun is seen, or any brightness, but there is a light which, though unseen, illumines the understanding.' Quoted in William P. Alston, Perceiving God (Ithaca: Cornell University Press, 1991), p. 13. 
with each other. For instance, one person can be prevented from sharing attention with another by boredom, distraction, insensitivity, or perceptual incapacity. Not every reason why a person could fail to share attention with others, however, seems to be one that affects the fulfilment of his interpersonal union with others. For it is possible to distinguish two sorts of obstacles to joint attention: (a) those that are caused by the lack of some faculty that enables joint attention, and (b) those that are not. For example, a person might be inhibited in his ability to share attention in the first way because of congenital blindness or autistic spectrum disorder. ${ }^{14}$ On the other hand, he might be inhibited in his ability in the second way because he habitually avoids contact with other people, despite having the faculties for sharing attention with them. Obstacles of the latter sort are relevant to the fulfilment of union between persons, since the union between two persons with all the faculties required for shared attention is greater insofar as they actually engage in joint attention. Obstacles of the former sort, however, seem less relevant to the fulfilment of union between persons, since the degree of union that is possible for two persons, one of whom lacks a faculty required for shared attention, is less than the degree of union that is possible for two persons who possess all the requisite faculties. Thus, if the fulfilment of interpersonal union between persons is nothing besides realizing the greatest degree of union possible between them, then the first type of obstacle to shared attention is not thereby an obstacle to the fulfilment of interpersonal union.

Turning to shared attention between God and human beings, it is plausible that the ways in which human beings could fail to share attention with God are similar to the ways in which they fail to share attention with each other. Thus, by analogy with the distinction above, it might be supposed that Mother Teresa experienced her dark night only because she lacked some faculty that is spiritually or psychologically

14 This not to say that persons affected by congenital blindness or autistic spectrum disorder cannot engage in joint attention at all. They can and do. My point is merely that the integrity of sensory and psychological capacities is necessary for full joint attention and that disruption to these capacities can constitute an obstacle to second-personal engagement. For the connections between shared attention, congenital blindness, and autism spectrum disorder, see R. Peter Hobson and Martin Bishop, 'The Pathogenesis of Autism: Insights from Congenital Blindness', in Autism: Mind and Brain (Oxford: Oxford University Press, 2004), pp. 109-125. 
necessary for someone to share attention with God. ${ }^{15}$ But if Mother Teresa's darkness could be explained by the mere lack of some faculty required for joint attention, then presumably her case would pose no challenge to Stump's claim concerning interpersonal union. For, when it is said that there is the fulfilment of union between two persons only if there is joint attention between those persons, the fulfilment in question is plausibly interpreted de re as 'the greatest degree of union possible given the faculties of the individuals involved. ${ }^{16}$ Consequently, if Mother Teresa simply lacked the requisite faculties for joint attention with God, then the greatest degree of union possible between her and God would be something considerably less than the degree of union she might have achieved with those faculties. Thus, the fulfilment of union between Mother Teresa and God would not require joint attention, since the greatest union open to her would be one that could be achieved without joint attention. As a result, Mother Teresa's failing to share attention with God during the dark night would not challenge Stump's view, interpreted as the claim that, 'for any human being with faculties for joint attention with God, the fulfilment of interpersonal union requires joint attention.'

The theological data, however, do not support this line of reasoning. Mother Teresa's perceived inability to communicate with God during her darkness is most evident in contrast to her extraordinary reported ability to communicate with God in intimate and loving ways at other times. For example, in September 1946, Mother Teresa was still a member of the Sisters of Loreto, and she was sent by train from Calcutta to Darjeeling for her annual retreat. During the journey, she had a mystical encounter with Christ, concerning which she later wrote:

[It] was a call within my vocation. It was a second calling. It was a vocation to give up even Loreto where I was very happy and to go out into the streets to serve the poorest of the poor. It was in that train,

15 One of Mother Teresa's most outspoken critics, Christopher Hitchens, makes a similar claim when he calls her darkness a 'personal crisis of faith': Christopher Hitchens, 'The Dogmatic Doubter', Newsweek, 10 September 2007, 40-42. See also his criticism of her charitable activities in Christopher Hitchens, The Missionary Position: Mother Teresa in Theory and Practice (London; New York: Verso, 1995).

16 This reading of the condition is supported by the fact that Stump consistently speaks of individuals as growing in the capacity for union to the extent that they are psychically integrated around the good: Stump, Wandering in Darkness, chap. 7; Eleonore Stump, 'Atonement and the Cry of Dereliction from the Cross', European Journal for Philosophy of Religion, 4 (2012), 1-17 (p. 2). 
I heard the call to give up all and follow Him into the slums - to serve Him in the poorest of the poor ... I knew it was His will and that I had to follow Him. ${ }^{17}$

Following this encounter, Mother Teresa received a series of interior locutions that lasted almost a year. Mother Teresa kept a record of 'what went on between Him and me during the days of much prayer', and she later called this record 'the copy of the Voice since September 1946. ${ }^{18}$ Although Mother Teresa desired to act immediately upon the 'second calling' that she discerned in her conversations with Christ, nevertheless, under the guidance of her spiritual director, Jesuit Father Céleste Van Exem, Mother Teresa for several months resisted Christ's call and remained silent about what it contained. Finally, however, in January 1947, Father Van Exem judged that Mother Teresa's inspiration was from God, and he permitted her to write the Archbishop of Calcutta, Ferdinand Périer, to inform him of what she believed God was calling her to do and to ask his permission to found a new religious order. In her letter to the Archbishop, Mother Teresa writes:

Your Grace,

From last Sept. strange thoughts and desires have been filling my heart. They got stronger and clearer during the 8 days retreat I made in Darjeeling ... One day at Holy Com.[Communion] I heard the same voice very distinctly - "I want Indian nuns, victims of My love, who would be Mary \& Martha, who would be so very united to Me as to radiate My love on souls ... Wilt thou refuse to do this for Me?" ... I tried to persuade Our Lord that I would try to become a very fervent holy Loreto nun, a real victim here in this vocation - but the answer came very clear again. "I want Indian Missionary Sisters of Charity - who would be My fire of love amongst the very poor - the sick - the dying - the little street children. - The poor I want you to bring to $\mathrm{Me}$ - and the Sisters that would offer their lives as victims of My love - would bring these souls to Me. You are I know the most incapable person, weak \& sinful, but just because you are that I want to use you, for My Glory! Wilt thou refuse?" These words or rather this voice frightened me. The thought of eating, sleeping - living like the Indians filled me with fear ... [But] the more I prayed - the clearer grew the voice in my heart and so I prayed that He would do with me whatever

17 Teresa, p. 40.

18 Teresa, p. 45. 
He wanted. He asked me again and again ... This is what went on between

Him and me during the days of much prayer. ${ }^{19}$

While Mother Teresa gives much additional evidence concerning her conversations with and visions of Christ, these passages are sufficient to suggest that Mother Teresa possessed considerable powers of spiritual discrimination. ${ }^{20}$ Under the guidance of Father Van Exem, Mother Teresa explicitly considered alternative construals of her experience, such as that it was the product of pride or self-delusion, ${ }^{21}$ and she finally rejected any alternate construal in favour of the view that God Himself was present to her. Further, Mother Teresa clearly distinguished between the types of experience, since, at certain times, she identified her state as one of hearing the voice of Christ, while at other times she identified her state as one of seeing Christ on the Cross amid the suffering poor. ${ }^{22}$ It adds to the credibility of her reports that Mother Teresa clearly differentiates between the content of her experiences and that she grew increasingly confident in characterizing her experience in the months leading up to her founding the Missionaries of Charity. Thus, Mother Teresa's experience of and response to extraordinary communication from God suggests that she possessed, on her own account, the required spiritual and psychological faculties to engage in joint attention with God. On the reasonable assumption that these faculties did not simply vanish as soon as she began to experience her dark night, it follows that, during her darkness, the mere absence of the relevant faculties was not a reason for Mother Teresa's failing to engage in joint attention with God.

\section{DARKNESS AND ABANDONMENT IN MOTHER TERESA'S DARK NIGHT}

In her private writings, Mother Teresa recounts that, shortly after founding the Missionaries of Charity in 1948, Mother Teresa felt herself to have lost all communication with God. In a letter to the Jesuit theologian Joseph Neuner, Mother Teresa contrasts her early experience

19 Teresa, pp. 47-49.

${ }^{20}$ For a similar argument concerning powers of spiritual discrimination, see Alston, p. 42. Notice also the interplay of 'I' and 'you' in this passage, indicative of a relationship that is plausibly second-personal, i.e., the kind of relationship that, in other contexts, is manifested in joint attention.

21 Teresa, p. 89.

22 Teresa, p. 101. 
of God's communication with the spiritual deafness and blindness that followed. She writes:

In Loreto, Father I was very happy. - I think the happiest nun. - Then the call came. - Our Lord asked directly - the voice was clear \& full of conviction. - Again \& again He asked in 1946. - I knew it was He ... The sweetness \& consolation \& union of those 6 months - passed but too soon ... Now Father - since [19] 49 or 50 this terrible sense of loss - this untold darkness - this loneliness - this continual longing for God which gives me that pain deep down in my heart. - Darkness is such that I really do not see - neither with my mind nor with my reason. - The place of God in my soul is blank. - There is no God in me. - When the pain of longing is so great - I just long \& long for God - and then it is that I feel - He does not want me - He is not there. ... God does not want me. - Sometimes - I just hear my own heart cry out - 'My God' and nothing else comes. - The torture and pain I can't explain. ${ }^{23}$

And, in a letter to a different spiritual director, she comments again on her inability spiritually to hear or see God, saying, ' ... the silence and emptiness is so great that I look and do not see, listen and do not hear ... '24 Together, these passages suggest that, for Mother Teresa, God's silence during her darkness stood in painful contrast to the clear and direct communication she received from God earlier in life. Not only did she lack the extraordinary locutions and visions that she knew before founding the Missionaries of Charity, but she seems also to have missed any ordinary awareness of God through her reason. On the contrary, it seemed to Mother Teresa that nothing of God remained within her, and, if we keep in mind her abilities for spiritual discrimination, we can conclude from this that God's apparent absence from her experience was not merely due to some general psychological or spiritual incapacity.

In addition to pointing out the absence of communication from God, Mother Teresa also mentions in the passage above her pain at feeling unwanted by God. Mother Teresa gives a typical example of her sense of unwantedness when she says that her spiritual state could be illustrated only by analogy to her beloved poor in the streets:

How cold - how empty - how painful is my heart. - Holy Communion Holy Mass - all the holy things of spiritual life - of the life of Christ in

${ }^{23}$ Teresa, pp. 1-2.

24 Teresa, p. 288. 
me - are all so empty - so cold - so unwanted. The physical situation of my poor left in the streets unwanted, unloved, unclaimed - are the true picture of my own spiritual life, of my love for Jesus ... ${ }^{25}$

From these passages we can see that, in addition to the lack of any communication from God, Mother Teresa's darkness was marked by a painful sense of God's absence and rejection.

From this brief summary of the theological data concerning Mother Teresa's dark night, it is clear that Mother Teresa experienced an interior torment arising from her sense of God's absence. Even if she had the faculties for sharing attention with God, Mother Teresa's sense of being abandoned by God demonstrates that she could not actually do so. To see this, consider the case of someone who believes that his friend neither communicates with him nor is present to him in any way. Such a person would be disposed to believe further that his friend is absent, in the sense that there is not any causal, communicative, or emotional interaction between himself and his friend. A person who believes that his friend is absent in this sense cannot be aware that he is sharing attention with his friend, since, even if he were merely mistaken in this belief (e.g., as through a hallucination), and his friend were actually present beside him, his unshakeable belief to the contrary precludes his believing that he is sharing attention with his friend. Indeed, the case of the person who believes his friend to be absent is relevantly similar to the case of the two persons who mistakenly believe the glass between them to be a one-way mirror. For, in each case, the beliefs of the participants preclude the sorts of iterative and introspective availability characteristic of joint attention. Someone who is fully convinced that his friend is entirely absent cannot perceive that his friend perceives him, and even less can he determine by introspection that the full openness of joint attention exists between him and his friend. Thus, even if we suppose that God was present to Mother Teresa during her darkness, and present in such a way that he was accessible for joint attention, nevertheless, Mother Teresa's belief that God was absent from her implies that she was in no position to share attention with God. 


\section{A RESPONSE FROM TRIADIC JOINT ATTENTION}

While the data concerning Mother Teresa's dark night of the soul seems to rule out her sharing attention with God, there is an additional piece of evidence concerning Mother Teresa's service to the poor that suggests an interesting reply for an advocate of Stump's claim about interpersonal union. In addition to describing her interior life of prayer, Mother Teresa also reflects on serving the poorest of the poor in Calcutta's slums. Turning to these reflections, we note that, while serving the poor, Mother Teresa experienced herself as working with a person present and living within her. She writes:

When outside - in the work - or meeting people - there is a presence - of somebody living very close - in very me. - I don't know what this is - but very often, even every day - that love in me for God grows more real. ${ }^{26}$

Here, Mother Teresa speaks about her 'work' outside the convent, work which involved both nursing the sick in their homes and gathering the homeless and dying from the street. In this work, Mother Teresa attended to the concrete needs of other people, but this passage suggests that Mother Teresa also experienced this service as with another person, a person whom she describes as 'somebody living very close - in very me'. Since she claims not to know what this somebody is, yet associates his presence with the increase of the love for God in her, it is plausible that, for Mother Teresa, the person with whom she experienced Christ's care for the poor was Christ himself. Thus, when serving the poor, Mother Teresa seemed both to carry out Christ's service to the poor and to serve them with Christ, living within her.

These features of Mother Teresa's experience move us to consider the distinction between two types of joint attention - dyadic and triadic joint attention - and to explore whether Mother Teresa could have engaged in triadic joint attention with God while serving the poor, even if she could not engage in dyadic joint attention with God during solitary prayer. ${ }^{27}$ Unlike dyadic joint attention, which is a person-person

26 Teresa, p. 211.

${ }^{27}$ For reflections on the distinction and interaction between dyadic and triadic joint attention, see Vasudevi Reddy, 'Before the "Third Element": Understanding Attention to Self', in Joint Attention: Communication and Other Minds: Issues in Philosophy and Psychology, ed. by Naomi Eilan and others (Oxford: Oxford University Press, 2005), pp. 86-109; Johannes Roessler, 'Joint Attention and the Problem of Other Minds', in Joint Attention: Communication and Other Minds: Issues in Philosophy and Psychology, 
scenario involving two people and their attention to each other, triadic joint attention is a person-person-object scenario involving two people and their attention to something distinct from themselves. Here is a typical case of triadic joint attention: suppose that someone is sitting on a park bench, watching a swan, and his friend comes to sit next to him on the bench. ${ }^{28}$ If they acknowledge each other's presence, then it is possible that the quality of their experience will shift from solitary attention to the swan to fully joint attention with each other. Once in this joint condition, each person is not the focus or object of the other's attention, since it is only the swan that each is attending to. Nevertheless, the other person is there, as co-attender, at the periphery of each one's experience, and as long as they are jointly attending to the swan they both share an awareness of their shared focus on it.

Return now to the case of Mother Teresa. An advocate of Stump's claim concerning interpersonal union might argue that the tension between Mother Teresa's dark night and Stump's claim is removed if it is possible that Mother Teresa engaged in what could be characterized as triadic joint attention with God. And, given Mother Teresa's comment about the presence of someone 'living very close' within her during her service, it does in fact seem possible that Mother Teresa engaged in triadic attention with God while at work, insofar as the sense of blindness, isolation, and rejection that ruled out her engaging in dyadic joint attention fails to rule out her engaging in triadic joint attention while working with the poor. For, while it is true that no one can engage in dyadic joint attention with another if he believes he cannot perceive the other, the same is not the case for triadic joint attention. In the swan example, the two friends do not see each other as they jointly attend to the swan, and they would most likely believe that they cannot see each other just as long as they attend to the swan together. Nevertheless, this belief does not prevent each one from being aware of the other's presence at the periphery of his experience. Thus, even if Mother Teresa lacked any sense of God's directly

ed. by Naomi Eilan and others (Oxford: Oxford University Press, 2005), pp. 230-259; Elisabeth Pacherie, 'The Phenomenology of Joint Action: Self-Agency Versus Joint Agency', in Joint Attention: New Developments in Psychology, Philosophy of Mind, and Social Neuroscience, ed. by Axel Seemann (Cambridge, MA: MIT Press, 2011), pp. 343390; Shaun Gallagher, 'Interactive Coordination in Joint Attention', in Joint Attention: New Developments in Psychology, Philosophy of Mind, and Social Neuroscience, ed. by Axel Seemann (Cambridge, MA: MIT Press, 2011), pp. 293-306.

${ }^{28}$ Campbell, 'Joint Attention and Common Knowledge', p. 288. 
communicating with her, such a lack of awareness is not an obstacle to her engaging in triadic attention with God while serving in the streets.

\section{EVALUATING THE TRIADIC ATTENTION RESPONSE}

The above response based on triadic attention displays a number of strengths. First, and most to the point, the response identifies a recognized mode of joint attention that seems consistent with the phenomenological characteristics of Mother Teresa's dark night. Second, the response helps to make sense of Mother Teresa's report of 'someone living very close within her', a comment that seems a strikingly apt description of how a co-attender might figure into the periphery of one's experience during triadic joint attention. Finally, the response suggests a reason why Mother Teresa did not lose her faith in God despite the pain of the dark night, since perhaps she grew in union with God through triadic engagement even while she longed for greater closeness of dyadic interaction.

Despite these advantages, however, the response from triadic attention will not work to save Stump's claim concerning interpersonal union. While it is clear that triadic joint attention allows co-attenders to have some awareness of each other without directly perceiving one another, it is less clear that the sort of awareness made possible by triadic attention alone is one that is conducive to interpersonal union. For, when we consider the ways in which a co-attender can be present at the periphery of one's experience in triadic joint attention, it is important not to confuse (a) the presence of the other as a person and (b) the presence of the other as some person in particular. Consider the following case of triadic attention described by Adam Green:

[I]f [persons] A and B are carrying a large piece of furniture up some stairs and A cannot see B, A still experiences the couch-carrying differently than A would if A thought he were carrying it alone. Even though A is focused on carrying the item up the stairs and may not even see $B, A$ is mediately aware of $B$... If $A$ reaches the top of the stairs only to realize that A was carrying the item alone, A will not think that an inferential error was made somewhere along the way. It will feel like an illusion. The experience ends up being of a different nature than it seemed to be at the time even if $\mathrm{A}$ was focused on the furniture and not on $\mathrm{B}$, the 
reason being that $A$ took himself/herself to be aware of $B$ in the way that $B$ affected A's sense of the weight and movement of the couch. ${ }^{29}$

In this example, person A cannot see person B while A and B carry the couch up the stairs together. Nevertheless, it is plausible that A and $B$ engage in triadic joint attention during this activity, insofar as they consciously coordinate their movements in order to navigate. If $\mathrm{A}$ and $B$ engage in triadic joint attention while moving the couch, it is clear that A and B each have some awareness of each other through how they each affect the couch's weight and movement. But if we suppose that the only engagement A and B have is this triadic one, and that, say, A and $\mathrm{B}$ do not acknowledge, recognize, or perceive each other before or after moving the couch, then the awareness that A and B have of each other through moving the couch will be merely as of another person and not as of some person in particular. Without some dyadic interaction to frame and contextualize the experience of the triadic interaction, the triadic interaction alone is nothing more than co-attention with an unidentified other.

Now, according to the triadic response, Mother Teresa engaged in triadic joint attention with God without dyadic joint attention. But if the argument above is correct, then Mother Teresa's awareness of God could have been only as of a person, not as of some person in particular. And this is precisely what we ought to conclude from revisiting her report of the one 'living within her':

When outside - in the work - or meeting people - there is a presence - of somebody living very close - in very me. - I don't know what this is - but very often, even every day - that love in me for God grows more real. ${ }^{30}$

It is tempting to interpret Mother Teresa's statement as implying that she did not know what sort of being it is that lived very close within her. If this is her meaning, then much less could she claim to know which being was living within her, and thus we could conclude that she had no awareness of God as living within her. But even if we take her statement to mean that she did not know what sort of phenomenon she was experiencing, the fact that she refers to the one living within her as 'somebody', combined

${ }^{29}$ Adam Green, 'Reading the Mind of God (without Hebrew Lessons): Alston, Shared Attention, and Mystical Experience', Religious Studies, 45 (2009), 455-470 (p. 468, original emphasis).

30 Teresa, p. 211. 
with the fact that Mother Teresa had ample experience of what she took to be direct converse with God, forces us to conclude that her experience of this person was not an awareness of some person in particular, much less an awareness of God himself.

Applying these results to Stump's claim concerning interpersonal union, we find ourselves forced to ask whether the type of joint attention required for the fulfilment of union with God is one in which human beings purportedly share awareness with God (a) merely as a person or (b) as some person in particular. Suppose, then, that only (a)-type, triadic joint attention is necessary. This would mean that, from the (firstperson) perspective of the human, the iterative availability of triadic joint attention would be the human's ability to know propositions of the form 'I perceive that $\mathrm{S}$ perceives [...] that I perceive that $\mathrm{O}$ ', where $\mathrm{O}$ is the object of joint attention, and $\mathrm{S}$ is a co-attender of which the human subject is aware merely as a person, but as a person unknown to him. Further, the introspective availability of the joint attention would be nothing other than the human's ability to perceive by introspection that he jointly attends an object with another person, but a person whose identity is obscure.

Put in this way, it is difficult to see how such encounters could make any sort of contribution to interpersonal unity. Even if we suppose that the object of joint attention is something that is suited to increase the union between God and the human subject (e.g., a homeless child whom one intends to care for), the fact that the subject's co-attender is unknown means that the joint attention itself can neither perfect the human subject nor draw him closer to God. Triadic joint attention with an unknown co-attender neither increases one's knowledge about the co-attender, nor increases one's desire to know him, nor removes obstacles to knowing him, since, beyond the fact that such joint attention could give little (if any) information about the co-attender, the subject cannot identify whom the information is about. At best, the unknown co-attender's presence at the periphery of the subject's experience might induce a certain wonder about who the co-attender is, but even if it is possible that such wonder is conducive to divine-human union, this should not convince us that joint attention in this sense is necessary for the fulfilment of union with God. Thus the response from triadic joint attention cannot both preserve Stump's claim and offer plausible way in which Mother Teresa could be said to engage in joint attention with 
God. If Mother Teresa engaged in triadic attention at all, it was a sort not necessary for interpersonal union.

\section{AN ALTERNATIVE SUGGESTION}

The difficulties that I have pointed out for Stump's view concerning joint attention and interpersonal union could be solved if there were a way to hold that human beings, while experiencing the dark night of the soul, can engage in joint attention with God without being aware of their doing so. Suppose that the thoughts and activities of a person are directed by God through joint attention, but that the person is not aware of God's involvement in directing his activities. Then God and the person will be united in their actions, but the person will not be in a position to know this. Stump is kept from such a solution by the assumption that joint attention is a sort of shared awareness of sharing of focus, so that she would then also have to say that joint attention is in fact not taking place.

In my view, the problem is insoluble for Stump because she assumes that joint attention occurs only if each party is aware that joint attention occurs. On this view, if someone is not aware that he is engaged in joint attention with another, or if he does not recognize the other with whom he is engaged, then he is not engaged in joint attention at all. Therefore, if someone, like Mother Teresa, is prevented by the dark night from becoming aware of sharing attention with God, then that person is prevented from sharing attention with God altogether. Consequently, if shared attention is necessary for the fulfilment of interpersonal union with God, such a person also lacks the fulfilment of interpersonal union.

Recent work in experimental psychology, however, suggests that a person's attention can influence his actions even if that person is not aware of what he is attending to or how his attention is being directed. For example, patients with blindsight retain the ability to detect, discriminate and localize objects in areas of their visual field in which they report that they are subjectively blind. ${ }^{31}$ Furthermore, despite

31 See Lawrence Weiskrantz, Blindsight: A Case Study Spanning 35 Years and New Developments (Oxford: Oxford University Press, 2009). For reflections on the epistemological significance of blindsight, see Ned Block, 'On a Confusion About a Function of Consciousness', Brain and Behavioral Sciences, 18 (1995), 227-247; Fred Dretske, 'What Good Is Consciousness?', Canadian Journal of Philosophy, 27 (1997), 1-15. For evidence suggesting that attention is not sufficient for phenomenological awareness in sighted persons, see R. W. Kentridge, T. C. W. Nijboer and C. A. Heywood, 'Attended 
lacking subjective awareness of the objects with which they interact, patients with blindsight still exhibit visually guided behaviours such as negotiating obstacle courses and correctly judging and reacting to others' facial expressions. ${ }^{32}$ It is likely, then, that human beings can attend to and process information about objects without being aware of them. More importantly, however, other research suggests that another's gaze or orientation towards an object can direct a person's attention and influence his actions towards that object without his being aware of it. ${ }^{33}$ This research suggests that, even if full joint attention requires awareness of the other, there is a way in which the causal conditions presupposed by joint attention can be met without a person's being aware of it. That is, it is possible that one of the causal factors sustaining a person's attention on an object might be that another is attending to that same object, even though the person has no explicit thoughts about the direction of the other's attention or awareness that the person is there. ${ }^{34}$

If these views about attention and awareness are correct, then there seems to be a different sort of joint attention that does not require a person to be aware that joint attention occurs. ${ }^{35}$ When this sort of joint attention occurs, one's attention is guided by the attention of another person, and one's sharing attention with the other leads to one's acting differently from how one would act in the absence of such joint attention. The entire process, however, occurs without one's being explicitly aware of the other.

This alternative form of joint attention suggests a different analogy by which we might understand Mother Teresa's experience of the dark

but Unseen: Visual Attention Is Not Sufficient for Visual Awareness', Neuropsychologia, 46 (2008), 864-9.

32 Beatrice de Gelder, 'Uncanny Sight in the Blind', Scientific American, 302 (2010), $60-65$.

${ }^{33}$ Jari K. Hietanen, 'Does Your Gaze Direction and Head Orientation Shift My Visual Attention?', Neuroreport, 10 (1999), 3443-3447; Wataru Sato, Takashi Okada, and Motomi Toichi, 'Attentional Shift by Gaze Is Triggered Without Awareness', Experimental Brain Research, 183 (2007), 87-94; Shan Xu, Shen Zhang and Haiyan Geng, 'GazeInduced Joint Attention Persists Under High Perceptual Load and Does Not Depend on Awareness', Vision Research, 51 (2011), 2048-2056.

${ }^{34}$ Campbell, 'Joint Attention and Common Knowledge', p. 288.

${ }^{35}$ Note a similar distinction between the causal and awareness conditions of joint attention in Timothy P. Racine, 'Getting Beyond Rich and Lean Views of Joint Attention', in Joint Attention: New Developments in Psychology, Philosophy of Mind, and Social Neuroscience, ed. by Axel Seemann (Cambridge, MA: MIT Press, 2011), pp. 21-42. 
night of the soul. I do not claim that this analogy is correct, or that it is the analogy that Stump would accept, or that it is the analogy that she ought to accept. My point is simply to show that the connection between interpersonal union and joint attention is not entirely severed by the dark night, and that there is at least one way in which someone enduring the dark night might lack awareness of God and yet share attention with him. Suppose then, on analogy with the different sort of joint attention described above, that Mother Teresa's attention and activities were directed by God's own attention. That is, suppose that God attended to and adopted a certain stance towards persons and objects in Mother Teresa's environment, and that God's attention and stance were factors sustaining Mother Teresa's own attention to and stance towards those persons and objects. Furthermore, suppose that during her darkness, Mother Teresa was affected by a sort of 'spiritual blindsight', according to which she lacked any awareness of God as directing her attention or stance towards other things. On this analogy, Mother Teresa's union with God would not be characterized by joint attention alone, but rather by the causal conditions underlying joint attention coupled to a state of spiritual perception similar to blindsight. For simplicity, let us call this analogy the 'blindsight view' of Mother Teresa's interaction with God.

If something like the blindsight view correctly describes Mother Teresa's condition in the dark night of the soul, ${ }^{36}$ we can say that Mother Teresa engaged in some sort of joint interaction with God without having to suppose that she was aware of her sharing attention with God. Moreover, this account helps us to explain the features of Mother Teresa's dark night that we have found to be incompatible with her sharing full joint attention with God. Indeed, on the blindsight view, Mother Teresa's sense of isolation and abandonment is explained by her lacking any subjective awareness of the object of her attention in prayer, and her failure to identify the person 'living within her' as some person in

\footnotetext{
${ }^{36}$ There is perhaps good theological reason to think that something like the blindsight view is correct for human beings enduring the dark night of the soul. For one thing, the Book of Psalms, which Christians have traditionally taken to describe every stage of spiritual development, is replete with references to God's 'hiding his face' from those who desire to see him (e.g., Psalms 30.7; 44.24; 69.17; 88.14; 89.46; 104.29). For another thing, mystics such as St. John of the Cross compare the dark night of the soul to the blindness that results from staring at the sun: God's extreme closeness to a person in the dark night renders him unable perceive spiritually (cf. John of the Cross, p. 335).
} 
particular is explained by her lacking any awareness of the one directing her attention to and stance towards the poor.

A further consequence of the blindsight view is that Mother Teresa's union with God had less to do with shared attention than with shared activity, and this consequence fits well with how Mother Teresa came to understand her darkness during the later parts of her life. For example, as she grew more at peace with her spiritual darkness, ${ }^{37}$ Mother Teresa came to characterize the union she enjoyed with God as a union not of affect, but a union of will and of work. She writes, 'I am not alone. - I have His darkness - I have His pain - I have the terrible longing for God - to love and not to be loved. I know I have Jesus - in that unbroken union for my mind is fixed on Him and in Him alone, in my will. ${ }^{38}$ And again: 'I know that I want with my whole heart what He wants, as He wants and for as long as He wants. Yet ... this "aloneness" is hard. The only thing that remains is the deep and strong conviction that the work is His. ${ }^{39}$ The blindsight view, however, provides a way of understanding a union of will and of work in a way that is compatible with one party feeling isolated from and rejected by the other. For, on the blindsight view, God's attention to and stance towards the poor sustained and directed Mother Teresa's own attention and stance, and consequently God and Mother Teresa came to will the same things in the same way. But despite willing the same things as God and being directed by him to serve others, Mother Teresa continued to feel isolated and alone insofar as she had no awareness of God as directing her work. Finally, the blindsight view goes some way towards explaining why the dark night of the soul contributed to interpersonal union between God and Mother Teresa. Mother Teresa recognized God's work in her activities, but she lacked any awareness of his presence as she carried them out. Her acute sense of God's absence, however, caused her to be even more attentive to God's commandments of love, and this in turn united her even more intimately to God's will. Thus, the blindsight view makes sense of Mother Teresa's experience in a way that is not possible based on joint attention alone.

\footnotetext{
${ }^{37}$ See, for example, Mother Teresa's 1974 letter to Fr. Don Kribs, where she comments that one's degree of interior 'emptiness' is proportionate to the degree to which God lives 'His life in us': Teresa, p. 275.

${ }^{38}$ Teresa, p. 223.

39 Teresa, p. 236.
} 


\section{CONCLUSION}

In this paper, I have examined a problem for Stump's claim that joint attention is necessary for the fulfilment of interpersonal union with God, a problem posed by the dark night of Mother Teresa. Mother Teresa's experience of darkness, isolation, and rejection is inconsistent with her engaging in dyadic joint attention with God. Furthermore, while some aspects of her service to the poor might seem to suggest that she engaged in triadic joint attention with God, I have argued that this view also must be rejected, since triadic joint attention with an unknown co-attender is not conducive to interpersonal union. Faced with these conclusions, I have suggested one way in which a person might be directed in his activities by God's own attention without being aware of God's involvement. On this 'blindsight view' of Mother Teresa's dark night of the soul, Mother Teresa's spiritual condition involved both the causal conditions presupposed in joint attention and also a sort of spiritual blindsight. Whether this proposal is ultimately coherent will also depend, however, on whether it can help us to make better sense of why the dark night of the soul, and thus spiritual blindsight, might be instrumental for increasing interpersonal union with God. This question promises to provide another fruitful avenue for engagement between cognitive science, psychology, and philosophical theology. ${ }^{40}$

\section{BIBLIOGRAPHY}

Akkoyunlu, E. A., K. Ekanadham, and R. V. Huber, 'Some Constraints and Tradeoffs in the Design of Network Communications', in Proceedings of the 5th ACM Symposium on Operating Systems Principles, ed. by James C. Browne and Juan Rodriguez-Rossell (New York: ACM, 1975), pp. 67-74 Alston, William P., Perceiving God (Ithaca: Cornell University Press, 1991) Block, Ned, 'On a Confusion About a Function of Consciousness', Brain and Behavioral Sciences, 18 (1995), 227-247

Campbell, John, 'An Object-Dependent Perspective on Joint Attention', in Joint Attention: New Developments in Psychology, Philosophy of Mind, and Social Neuroscience, ed. by Axel Seemann (Cambridge, MA: MIT Press, 2011), pp. $415-430$

${ }^{40}$ Thanks to Eleonore Stump, John Greco, Andrew Pinsent, Lawrence Feingold, Errin Clark, Robert Hartman, Max Parish, Jeremy Skrzypek, and participants in the 2013 Ian Ramsey Centre Conference on the Second-Person Perspective for helpful comments on earlier drafts of this paper. 
Campbell, John, 'Joint Attention and Common Knowledge', in Joint Attention: Communication and Other Minds: Issues in Philosophy and Psychology, ed. by Naomi Eilan, Christoph Hoerl, Teresa McCormack, and Johannes Roessler (Oxford: Oxford University Press, 2005), pp. 287-297

Dretske, Fred, 'What Good Is Consciousness?', Canadian Journal of Philosophy, 27 (1997), 1-15

Gallagher, Shaun, 'Interactive Coordination in Joint Attention', in Joint Attention: New Developments in Psychology, Philosophy of Mind, and Social Neuroscience, ed. by Axel Seemann (Cambridge, MA: MIT Press, 2011), pp. 293-306

Garrigou-Lagrange, Reginald, Christian Perfection and Contemplation, According to St. Thomas Aquinas and St. John of the Cross, ed. by M. Timothea Doyle (St. Louis, MO: B. Herder Book Co., 1937)

Gelder, Beatrice de, 'Uncanny Sight in the Blind', Scientific American, 302 (2010), 60-65

Green, Adam, 'Reading the Mind of God (without Hebrew Lessons): Alston, Shared Attention, and Mystical Experience', Religious Studies, 45 (2009), $455-470$

Hietanen, Jari K., 'Does Your Gaze Direction and Head Orientation Shift My Visual Attention?', Neuroreport, 10 (1999), 3443-3447

Hitchens, Christopher, 'The Dogmatic Doubter', Newsweek, 10 September 2007, $40-42$

Hitchens, Christopher, The Missionary Position: Mother Teresa in Theory and Practice (London; New York: Verso, 1995)

Hobson, R. Peter, 'What Puts the Jointness into Joint Attention?', in Joint Attention: Communication and Other Minds: Issues in Philosophy and Psychology, ed. by Naomi Eilan, Christoph Hoerl, Teresa McCormack, and Joannes Roessler (Oxford: Oxford University Press, 2005)

Hobson, R. Peter, and Martin Bishop, 'The Pathogenesis of Autism: Insights from Congenital Blindness', in Autism: Mind and Brain (Oxford: Oxford University Press, 2004), pp. 109-125

John of the Cross, The Collected Works of St. John of the Cross, ed. by Kieran Kavanaugh and Otilio Rodriguez (Washington, D.C: Institute of Carmelite Studies, 1979)

Kentridge, R. W., T. C. W. Nijboer, and C. A. Heywood, 'Attended but Unseen: Visual Attention Is Not Sufficient for Visual Awareness', Neuropsychologia, 46 (2008), 864-9

Marin, Antonio Royo, and Jordan Aumann, The Theology of Christian Perfection (Dubuque, Iowa: Priory Press, 1962)

Mother Teresa, Mother Teresa: Come Be My Light: The Private Writings of the Saint of Calcutta, ed. by Brian Kolodiejchuk (New York: Image, 2007) 
Pacherie, Elisabeth, 'The Phenomenology of Joint Action: Self-Agency Versus Joint Agency', in Joint Attention: New Developments in Psychology, Philosophy of Mind, and Social Neuroscience, ed. by Axel Seemann (Cambridge, MA: MIT Press, 2011), pp. 343-390

Peacocke, Christopher, 'Joint Attention: Its Nature, Reflexivity, and Relation to Common Knowledge', in Joint Attention: Communication and Other Minds: Issues in Philosophy and Psychology, ed. by Naomi Eilan, Christoph Hoerl, Teresa McCormack, and Johannes Roessler (Oxford: Oxford University Press, 2005), pp. 298-324

Racine, Timothy P., 'Getting Beyond Rich and Lean Views of Joint Attention', in Joint Attention: New Developments in Psychology, Philosophy of Mind, and Social Neuroscience, ed. by Axel Seemann (Cambridge, MA: MIT Press, 2011), pp. 21-42

Reddy, Vasudevi, 'Before the "Third Element": Understanding Attention to Self', in Joint Attention: Communication and Other Minds: Issues in Philosophy and Psychology, ed. by Naomi Eilan, Christoph Hoerl, Teresa McCormack, and Johannes Roessler (Oxford: Oxford University Press, 2005), pp. 86-109

Roessler, Johannes, 'Joint Attention and the Problem of Other Minds', in Joint Attention: Communication and Other Minds: Issues in Philosophy and Psychology, ed. by Naomi Eilan, Christoph Hoerl, Teresa McCormack, and Johannes Roessler (Oxford: Oxford University Press, 2005), pp. 230-259

Sato, Wataru, Takashi Okada, and Motomi Toichi, 'Attentional Shift by Gaze

Is Triggered Without Awareness', Experimental Brain Research, 183 (2007), 87-94

Schilbach, Leonhard, Bert Timmermans, Vasudevi Reddy, Alan Costall, Gary Bente, Tobias Schlicht, and others, 'A Second-Person Neuroscience in Interaction', Behavioral and Brain Sciences, 36 (2013), 441-462

Stump, Eleonore, 'Atonement and the Cry of Dereliction from the Cross', European Journal for Philosophy of Religion, 4 (2012), 1-17

Stump, Eleonore, Wandering in Darkness: Narrative and the Problem of Suffering (Oxford: New York: Oxford University Press, USA, 2010)

Weiskrantz, Lawrence, Blindsight: A Case Study Spanning 35 Years and New Developments (Oxford: Oxford University Press, 2009)

Wilby, Michael, 'The Simplicity of Mutual Knowledge', Philosophical Explorations, 13 (2010), 83-100

$\mathrm{Xu}$, Shan, Shen Zhang, and Haiyan Geng, 'Gaze-Induced Joint Attention Persists Under High Perceptual Load and Does Not Depend on Awareness', Vision Research, 51 (2011), 2048-2056 